\title{
PENERAPAN MODEL PEMBELAJARAN GROUP INVESTIGATION UNTUK MENINGKATKAN KETERAMPILAN METAKOGNITIF SISWA KELASVII SMP NEGERI 4 LAMBOYA
}

\author{
Agustinus Jawu Kalaga ${ }^{1}$, Deny Setiawan ${ }^{2}$ \\ ${ }^{1}$ Mahasiswa IKIP Budi Utomo, Jl. Citandui No. 46 Malang \\ ${ }^{2}$ Dosen IKIP Budi Utomo, Jl. Citandui No. 46 Malang \\ e-mail: Aguskalaga29@gmail.com
}

\begin{abstract}
Based on interviews and observations, the metacognitive skills of the seventh grade students of SMP Negeri 4 Lamboya are still low. This is because the thinking skills have not been empowered in school. Need effort to overcome this, one way that is implementation of learning model study of Group Investigation (GI). The purpose of applying the Group Investigation learning model (GI) to improve students' metacognitive skills. This research is a class action research (PTK) consisting of 4 stages of Planning, Action, Observation, Reflection which is implemented in two cycles. The subjects of the study were students of class VII A SMP Negeri 4 Lamboya academic year 2016/2017 as many as 23 students. The results showed that the percentage of masakognitif skill resulted from (51.08) in cycle I to $(73,52)$ in cycle II. The conclusion of this research is Group Investigation study model (GI) can improve metacognitive skill of class VII A student of SMP Negeri 4 Lamboya.
\end{abstract}

Keywords: Metacognitive Skills, Group Investigation Learning Model (GI).

\section{PENDAHULUAN}

Berdasarkan hasil observasi dan wawancara untuk mengetahui situasi dan kondisi dalam pembelajaran IPA Kelas VII A SMP Negeri 4 Lamboya pada bulan November 2016, diketahui bahwa keterampilan metakognitif siswa masih tergolong rendah. Rendahnya keterampilan metakognitif siswa dapat diketahui dari nilai hasil belajar yang rendah pada ulangan harian yang dilaksanakan sebelumnya. Selain itu, dapatditunjukkan dari siswa masih belum terbiasa mempersiapkan pembelajaran yang dilakukannya serta memantau sejauh mana pengetahuan yang telah diperolehnya.

Moore\& Dwyer (2004) menyatakan bahwa metakognitif merupakan kesadaran berpikir seseorang tentang proses-proses berpikirnya sendiri baik tentang apa yang diketahui maupun apa yang akan dilakukan. Dengan demikian metakognitif melibatkan kesadaran seseorang untuk berpikir dan bertindak. Keterampilan metakognitif menunjukkan kemampuan berpikir tingkat tinggi, karena mencakup kontrol aktif terhadap proses-proses kognitif siswa dalam belajar dan berkaitan dengan kecerdasan (Livingston, 1997).Hal ini dapat berarti bahwa keterampilan metakognitif memiliki kaitan dengan kemampuan kognitif seseorang.

Beberapa hasil penelitian lain juga menunjukkan keterampilan metakognitif siswa rendah akibat pembelajaran yang dilakukan di kelas. Qodria (2014) mengungkap kekurangsiapan siswa dalam mempelajari materi pembelajaran dikelas. Masalah lain yang muncul adalah guru juga 
kurang memberdayakan kemampuan berpikir siswa. Hal ini terbukti dengan guru yang masih menerapkan pembelajaran yang bersifat teacher centered sehingga membuat siswa sering diam, hanya mendengarkan dan mencatat penjelasan guru. Sebagian besar pertanyaan yang diberikan oleh guru masih pada tingkat kognitif $\mathrm{C} 1$ sampai $\mathrm{C} 3$ dan jawabannya sudah ada dibuku teks, sehingga siswa hanya menyalin materi yang ada tanpa memahami isi pertanyaan dan jawaban yang mereka tulis.

Penelitian yang dilakukan Ardila (2013) juga menunjukkan bahwa keterampilan metakognitif siswa masih belum dapat berkembang dengan baik. Hal ini dapat terlihat dari siswa yang hanya belajar saat ada tugas rumah atau pun ujian dan mencontek pekerjaan teman.

Berdasarkan masalah tersebut, perlu upaya lebih lanjut untuk memberdayakan keterampilan metakognitif. Hal ini karena keterampilan metakognitif memungkinkan siswa untuk dapat berkembang menjadi pelajar yang mandiri karena mereka dibimbing untuk menjadi manajer bagi diri mereka sendiri, mampu menilai pemikiran, dan pembelajarannya sendiri (Susantini, 2004). Pemberdayaan keterampilan metakognitif juga dapat meningkatkan mutu pembelajaran yang rendah di kelas.

Mutu pembelajaran yang rendah bias diakibatkan dari proses pembelajaran yang dilaksanakan kurang efektif. Penyebabnya dapat berasal dari siswa, guru, minat dan motivasi siswa yang rendah, kinerja guru, serta sarana dan prasarana yang kurang memadai akan menyebabkan pembelajaran yang kurang efektif. Adanya kesempatan belajar ataupun melakukan aktivitas sendiri oleh siswa dalam suatu pengajaran merupakan pengajaran yang efektif. Hal ini sejalan dengan pendekatan cooperative learning dalam pembelajaran yang menekankan bahwa siswa harus secara aktif membangun pengetahuan dan keterampilannya. Untuk mewujudkan pembelajaran tersebut, diperlukan suatu model pembelajaran yang sesuai. Salah satu model pembelajaran adalah model pembelajaran Group Investigation (GI).

Model pembelajaran $G I$ diharapkan dapat meningkatkan keterampilan metakognitif siswa. Hal ini karena model pembelajaran GI memiliki sintaks pembelajaran yang mengharuskan siswa untuk menggunakan kemampuan berpikir level tinggi. Secara garis besar model pembelajaran GI memiliki enam tahap utama yaitu identifikasi topik, perencanan investigasi, pelaksanaan investigasi, persiapan laporan akhir, presentasi laporan akhir, dan evaluasi. Keenam tahap tersebut berpotensi untuk melatih keterampilan berpikir siswa.

Model pembelajaran GI memiliki kelebihan antara lain memberi kebebasan kepada siswa untuk berpikir secara analitis, kritis, kreatif dan produktif (Dewi dkk, 2012). GI mampu mengembangkan kemampuan kognitif maupun psikomotor siswa, membuat siswa tertarik mengikuti proses pembelajaran, merasa senang saat pembelajaran dan membuat pemahaman materi lebih mudah, karena siswa melihat secara langsung dan melakukan pengamatan sendiri masalah yang dihadapi dalam pembelajaran

Model pembelajaran GI juga berpotensi memberikan pengalaman belajar yang menarik bagi siswa, karena siswa merencanakan, melaksanakan, melaporkan, dan mengevaluasi hal-hal yang akan dipelajarinya sehingga dapat memberikan pembelajaran yang bermakna dan konsep yang didapat selama pembelajaran dapat melekat dalam ingatan siswa dalam jangka 
waktu yang lama (Wijayanti, 2013 dalam Alaslahah 2016).

Berangkat dari permasalahan tersebut, diharapkan model GI mampu meningkatkan keterampilan metakognitif siswa, terutama di SMP Negeri 4 Lamboya. Dengan demikian, penelitian ini bertujuan untuk meningkatkan keterampilan metakognitif siswa kelas VII A SMP Negeri 4 Lamboya melalui penerapan model pembelajaran Group Investigation (GI).

\section{METODE PENELITIAN}

Jenis penelitian yang digunakan dalam penelitian ini adalah Penelitian Tindakan Kelas (PTK). Penelitian Tindakan Kelas ini dilakukan dengan mengintegrasikan model pembelajaran GI. Penelitian dilakukan dalam 2 siklus, di mana dalam setiap siklus terdapat empat tahap, yaitu perencanaan, pelaksanaan, observasi, dan refleksi.

Kehadiran peneliti dalam penelitian ini adalah sebagai guru model yang merancang kegiatan pembelajaran atau tindakan. Penelitian dilaksanakan di Kelas VII A SMP Negeri 4 Lamboya selama semester genap Tahun Ajaran 2016/2017 pada Bulan Januari sampai Maret 2017.

Subjek penelitian ini adalah siswa kelas VII A dengan jumlah 23 siswa. Teknik pengumpulaan data yang digunakan dalam penelitian adalah tes esai dan diukur dengan rubrik keterampilan metakognitif yang dikembangkan oleh Corebima (2008). Tes esai dilakukan setiap akhir siklus. Teknik analisis data dilakukan dengan analisis deskriptif data kuantitatif dari siklus I dan Siklus II.

\section{HASIL DAN PEMBAHASAN Siklus I}

Pada tahap perencanaan tindakan, dilakukan penentuan materi yang akan dibahas pada siklus I, menyiapkan Silabus, Rencana Pelaksanaan Pembelajaran (RPP), Lembar Kerja Siswa (LKS), menyiapkan rubrik keterampilan metakognitif, dan menyusun kisi-kisi tes akhir siklus I untuk mengukur hasil keterampilan metakognitif siswa. Dari tahap perencanaan ini dihasilkan perangkat pembelajaran yang siap digunakan dalam tahap pelaksanaan tindakan.

Pada tahap pelaksanaan tindakan dilakukan dalam 4 pertemuan atau 4 kali membuka pelajaran. Tiap membuka pelajaran dilakukan memberikan apersepsi tentang materi yang akan dibahas berkaitan dengan kehidupan sehari-hari dengan bantuan penggunaan LKS.

Berdasarkan hasil pengamatan penilaian keterampilan metakognitif selama siklus I, nilai rata-rata keterampilan metakognitif 51,08. Jika dibandingkan dengan nilai KKM yang ditentukan oleh sekolah yaitu 65 , dapat berarti bahwa rata-rata masih belum mencapai dan hasil masih tergolong kategori cukup.

Pada tahap refleksi didapatkan hasil yang cukup baik, yaitu kebiasaan siswa dalam berpendapat mulai tumbuh dan keterampilan metakognitif siswa sudah mulai meningkat. Meskipun demikian, masih perlu dilakukan siklus sebelumnya karena tujuan masih belum tercapai.

\section{Siklus II}

Pada tahap perencanaan tindakan, dilakukan penentuan materi yang akan dibahas pada siklus II, menyiapkan Silabus, Rencana Pelaksanaan Pembelajaran (RPP), Lembar Kerja Siswa (LKS), menyiapkan rubrik keterampilan metakognitif, dan menyusun kisi-kisi soal tes akhir siklus II untuk mengukur hasil keterampilan metakognitif siswa.Dari tahap perencanaan ini dihasilkan perangkat pembelajaran yang siap 
digunakan dalam tahap pelaksanaan tindakan.

Pada tahap pelaksanaan tindakan dilakukan dalam 4 pertemuan atau 4 kali membuka pelajaran. Tiap membuka pelajaran dilakukan memberikan apersepsi tentang materi yang akan dibahas berkaitan dengan kehidupan sehari-hari dengan bantuan penggunaan LKS. Berdasarkan hasil pengamatan keterampilan metakognitif siswa selama siklus II, nilai rata-rata keterampilan metakognitif menjadi 73,52.

Pada tahap refleksi didapatkan hasil yang cukup baik, yaitu kebiasaan siswa dalam berpendapat mulai tumbuh dan keterampilan metakognitif siswa sudah mulai meningkat. Pada siklus II yang terlaksana, dengan adanya penerapan model pembelajaran GI guru dapat memperbaiki beberapa kekurangan pada setiap pertemuan. Salah satu ke-kurangan yang diperbaiki di siklus II ini adalah guru model sudah memaksimalkan kekurangan-kekurangan yang terdapat pada siklus I memfasilitasi siswa yang kurang aktif dalam pelaksanaan investigasi, presen-tasi tugas akhir dan penggunaan buku sumber belajar.

Pemaksimalan proses pembelajaran dan penggunaan buku sumber tersebut adalah saat guru membantu siswa berorientasi pada masalah yang sedang didiskusikan oleh siswa, yaitu dalam penugasan mengerjakan tugas yang berbentuk LKS. Terkait dengan penggunaan LKS yang digunakan dalam proses pembelajaran, terutama konsep, siswa sudah mulai dapat membedakan antara fakta dan konsep serta mulai menuliskan jawaban berdasarkan hasil diskusi yang didapatkan selama pembelajaran. Jika dibandingkan dengan nilai KKM yang ditentukan oleh sekolah yaitu 65 ini sudah mencapai dan hasil sudah tergolong kategori sangat baik dan penelitian dihentikan.

Tabel data terkait peningkatan hasil keterampilan metakognitif berdasarkan hasil tes yang didapatkan dengan menggunakan penskoran rubrik, siklus I ke siklus II tercantum pada Tabel 1.

Tabel 1. Perbandingan Nilai Hasil Tes Akhir Siklus I dan Siklus II

\begin{tabular}{ccc}
\hline & SIKLUS I & SIKLUS II \\
\cline { 2 - 3 } & Keterampilan Metakognitif & Keterampilan Metakognitif \\
\hline Jumlah & $\mathbf{1 1 7 5}$ & $\mathbf{1 6 9 1}$ \\
\hline Rata-Rata & $\mathbf{5 1 , 0 8}$ & $\mathbf{7 3 , 5 2}$ \\
\hline
\end{tabular}

Berdasarkan Tabel 1 diperoleh data bahwa nilai rata-rata siswa tes akhir siklus I keterampilan metakognitif siswa mengalami peningkatan di siklus II. Dimana dari 23 siswa hasil keterampilan metakognitif disiklus I yaitu 51,08 mengalami peningkatan di siklus II yaitu 73,52.

\section{Pembahasan}

Berdasarkan hasil analisis data siklus I dan II, diketahui bahwa dengan penerapan model pembelajaran GI terdapat peningkatan ketuntasan keterampilan metakognitif. Pada siklus I, ada beberapa kendala dalam melaksanakan proses pembelajaran untuk meningkatkan keterampilan metakognitif yaitu kurangnya rasa keingintahuan siswa dalam belajar, siswa juga cenderung pasif, tidak berani mengungkapkan pendapat atau pertanyaan, siswa kurang dapat mengekspor kemampuan yang mereka miliki, siswa kurang memiliki rasa percaya diri ketika dilakukan tes dan siswa tidak pernah diminta oleh guru untuk menerapkan/ mengaplikasikan konsep dan keterampilan yang telah 
dimiliki dalam situasi baru sehingga pembelajaran dirasakan siswa kurang bermakna serta kemampuan pemecahan masalah materi biologi siswa masih relatif rendah.

Peningkatan keterampilan metakognitif siswa pada pembelajaran IPA melalui penerapan model pembelajaran GI dapat terjadi karena dalam pembelajaran GI menggunakan LKS dalam diskusi kelompok, masing-masing siswa bertanggung jawab menyelesaikan tugas yang diberikan melalui LKS, maka menuntut siswa untuk bekerjasama dan berargumentasi dalam memecahkan masalah. Hal ini selaras dengan (Erlisnawati \& Mahardi, 2014) model pembelajaran GI memberikan kesempatan bagi siswa untuk menentukan topik permasalahannya sendiri kemudian berusaha menyelesaikan permasalahan tersebut secara investigasi kelompok. Melalui kegiatan investigasi kelompok, siswa akan berusaha menentukan langkah-langkahnya sendiri guna mencari penyelesaian yang tepat.

Pembelajaran kooperatif GI berpotensi memberdayakan keterampilan metakognitif siswa karena sintaks pembelajaran kooperatif GI mereka belajarsaling membantu, berdiskusi, dan berargumentasi untuk memahami, mengerti, dan mengetahui suatu topik secara bersama, serta menuntut tanggung jawab individu untuk menguasai materi ajar (Slavin, 2010).

Dengan model pembelajaran GI siswa akan terlatih untuk memecahkan masalah melalui langkah-langkah yang telah disusun bersama kelompok investigasi sehingga mampu meningkatkan kemandirian siswa dalam belajar. Kemandirian siswa dalam belajar menunjukkan adanya kesadaran siswa akan proses berpikirnya. Siswa yang sadar akan proses berpikir mereka untuk belajar makaakan dapat menentukan tujuan dan memusatkan perhatiannya sehingga akan berdampak pada keterampilan metakognitifnya. Dengan kata lain, Siswa yang memiliki keterampilan metakognisi tinggi dapat mengontrol kognitifnya sehingga mencapai ketuntasan belajar (Primasari, dkk, 2015)

Fakta yang menunjukkan bahwa keterampilan metakognitif meningkat yaitu penelitian dengan model kooperatif yang berbeda yang dilakukan oleh Setiawan \& Susilo (2015), dimana peningkatan hasil tes akhir siklus setelah dianalisis dengan rubrik keterampilan metaognitif menunjukkan ada peningkatan keterampilan metakognitif sebesar $16 \%$, dengan rincian pada siklus I sebesar $62 \%$ dan siklus II sebesar $78 \%$.

Fakta lain yang menunjukkan bahwa keterampilan metakognisi meningkat yaitu penelitian yang dilakukan oleh Primasari, dkk (2015), hasil analisis data diketahui bahwa jumlah siswa yang memiliki kategori keterampilan metakognisi "Baik" mengalami peningkatan dari 13 siswa pada siklus I menjadi 16 siswa pada siklus II. Jumlah siswa yang termasuk kategori "Baik Sekali" juga mengalami peningkatan dari 7 siswa pada siklus I menjadi 16 siswa pada siklus II. Meningkatnya jumlah siswa yang termasuk kategori "Baik" dan "Baik Sekali" ini menunjukkan bahwa kesadaran siswa tentang pentingnya belajar dan apa tujuan mereka belajar mengalami peningkatan yang signifikan. Hal ini sangat berhubungan dengan model pembelajaran yang digunakan.

\section{SIMPULAN DAN SARAN}

Kesimpulan dari penelitian penerapan Model Pembelajaran Group Investigation (GI) di kelas VII A SMP Negeri 4 Lamboya adalah dapat meningkatkan Keterampilan Metakognitif Siswa dari $51,08 \%$ di siklus Imenjadi 73,52 pada siklus II. 
Penerapan model pembelajaran GI memerlukan pengelolaan kelas yang baik, sehingga seluruh siswa memperoleh perhatian yang sama dan guru perlu memberikan suatu perdebatan yang berarti supaya siswa merasa lebih me-nyenangkan dalam pembelajaran, seperti dibuat adanya pertanyaan yang harus dijawab secara rebutan oleh seluruh siswa.

Saran bagi penelitian selanjutnya dapat dilakukan penerapan model untuk mengukur ke variabel lain, seperti kemampuan berpikir lain, seperti berpikir kreatif, kerjasama maupun komunikatif, sehingga mampu menunjang kemampuan abad 21.

\section{DAFTAR PUSTAKA}

Ardila, C. 2013. Hubungan Keterampilan Metakognitif terhadap Hasil Belajar Biologi dan Retensi Siswa Kelas X dengan Penerapan Strategi Pembelajaran Berpikir Melalui Pertanyaan (PBMP) di SMAN 9 Malang. Skripsi tidak diterbitkan. Malang: Jurusan Biologi UM.

Erlisnawati \& Marhadi, H. (2014). Penerapan Model Pembelajaran Tipe Group Investigation Untuk Meningkatkan Hasil Belajar IPS Siswa Kelas IV SD Negeri 56 Pekanbaru. Jurnal Primary, 3 (1): 9-14.

Livingston, J. A. 1997. Metacognition: An Overview, (Online) (http://www.gse.bufallo.edu/fas/shuell/ cep564/metacog.htm), diakses pada 12 Oktober 2016.

Moore, D. M., \& Dwyer, F. M. (2001). The Relationship of Field Dependence and Color-coding to female students' achievement. Perceptual and Motor Skills, 93:81-85.

Primasari, YA, Anggraini, R, Wibowo, BCA, Primandiri, PR, \& Santoso, AM. 2015.
Implementasi Model Pembelajaran Group Investigation Berbasis Local Materials Melalui Lesson Study untuk Meningkatkan Keterampilan Metakognisi dan Hasil Belajar Kognitif Siswa Kelas XSMAN 1 Mojo Kediri pada Materi Ekosistem. Prosiding Seminar Nasional XII FKIP UNS 2015. Qodria, L. 2014. Pengararuh Strategi Pembelajaran PGMP dan PBMP dipadu TPS terhadap Keterampilan Metakognitif dan Hasil Belajar Kognitif Biologi Siswa Kelas XI dengan Kemampuan Akademik Berbeda di Malang. Skripsi. Skripsi tidak ditebitkan. Malang. Jurusan Biologi UM.

Setiawan, D \&Susilo, H. 2015. Peningkatan Keterampilan Metakognitif Mahasiswa Program Studi Biologi melalui Penerapan Jurnal Belajar dengan Strategi Jigsaw Dipadu PBL Berbasis Lesson Study pada Matakuliah Biologi Umum. Prosiding Seminar Nasional Pendidikan Biologi 2015. Malang 21 Maret 2015

Slavin, RE. 2010. Cooperative Learning Teori, Riset dan Praktik. Bandung: Nusa Media.

Susantini, E. 2004.Memperbaiki Kualitas

Proses Belajar Genetika Melalui Strategi Metakognitif dalam Pembelajaran Kooperatif pada Siswa $S M U$. Disertasi tidak diterbitkan. Malang: PPs UM

Wijayanti, W. 2013. Pengaruh Model Pembelajaran Group Investigation (GI) terhadap Kemampuan Berpikir Kritis Siswa Kelas X SMA Negeri Mejayan Kabupaten Madiun. Skripsi tidak diterbitkan. Malang: Jurusan Geografi UM. 